\title{
Pengaruh Disiplin Kerja dan Motivasi Kerja Terhadap Kinerja Pegawai Negeri Sipil Pada Badan Keuangan Kabupaten Lima Puluh Kota
}

\author{
Hariman Syaleh ${ }^{1}$ dan Rohimah Nur Nasution ${ }^{2}$ \\ 1Sekolah Tinggi Ilmu Ekonomi Haji Agus Salim Bukittinggi \\ 2AKPAR Paramitha Bukittinggi \\ Email : harimansyaleh@yahoo.co.id
}

\begin{abstract}
This study aims to analyze the effect of work discipline and work motivation on the performance of civil servants at the Financial Agency of Fifty Cities Regency. Here the author describes the influence of work discipline and work motivation on performance. The total population in this study were 72 people as well as samples in this study. Data were collected through the distribution of a questionnaire with a Likert scale model and then tested for the validity and reliability of the questionnaire. The purpose of multiple linear regressions is to see the relationship between the influence of the independent variable on the dependent variable. The results of this study are a). Work discipline (X1) has a positive and significant influence on the performance of civil servants at the Fifty Cities District Finance Agency. b). Work motivation (X2) has a positive and significant influence on the performance of civil servants at the Fifty Cities District Finance Agency. c). Work discipline and work motivation together have a significant positive effect on the Performance of Civil Servants at the Financial Agency of Fifty Cities Regency.
\end{abstract}

Keywords: Discipline, Motivation, and Performance

\section{Pendahuluan}

Dalam rangka melaksanakan amanat Peraturan Pemerintah Nomor 8 Tahun 2008 tentang Tahapan, Tata Cara Penyusunan, Pengendalian dan Evaluasi maka Badan Keuangan Kabupaten Lima Puluh Kota melakukan Pengelolaan keuangan daerah yang merupakan tugas dan fungsi pokok DPPKAD yang berdasarkan Peraturan Pemerintah Nomor 58 Tahun 2005 tentang Pengelolaan Keuangan Daerah, bahwa keuangan daerah harus dikelola secara tertib, efisien, ekonomis, efektif, transparan dan bertanggung jawab sesuai dengan azas kepatutan dan rasa keadilan.

Pemerintah Kabupaten Lima Puluh Kota pelaksanaan pengelolaan keuangan daerah berpedoman pada Undang-Undang Nomor 17 Tahun 2003 tentang Keuangan Negara, Undang-Undang Nomor 1 Tahun 2004 tentang Perbendaharaan Negara, Peraturan Pemerintah Nomor 58 Tahun 2005 tentang Pengelolaan Keuangan Daerah, Peraturan Menteri Dalam Negeri (Permendagri) Nomor 13 Tahun 2006. Pemendagri Nomor 59 Tahun 2007 tentang Pedoman Pengelolaan Keuangan Daerah dan secara spesifik pengelolaan keuangan Daerah Kabupaten Lima Puluh Kota diatur dalam Peraturan Daerah Kabuapten Lima Puluh Kota 
Nomor 1 Tahun 2008 tentang Pokok - Pokok Pengelolaan Keuangan Daerah. Pengelolaan Keuangan Daerah Kabupaten Lima Puluh Kota dilaksanakan dalam suatu sistem terintegrasi diwujudkan dalam APBD yang setiap tahun ditetapkan dengan Peraturan Daerah. APBD merupakan instrumen yang menjamin terciptanya disiplin dalam proses pengambilan keputusan terkait dengan kebijakan pendapatan maupun belanja daerah.

Keberhasilan dan kegagalan pembangunan tidak dapat lepas dari peran yang dimainkan oleh aparatur pemerintahan sebagai abdi negara dan abdi masyarakat. Di samping itu latar belakang pendidikan dan pengalaman kerja pegawai juga berpengaruh terhadap perilaku pegawai dalam melaksanakan tugas-tugasnya. Dan pegawai negeri juga diberikan peluang untuk mengikuti pendidikan yang lebih tinggi. Dengan pendidikan yang lebih tinggi diharapkan pegawai negeri dapat meningkatkan pelayanan kepada masyarakat. Secara ringkas dapat dikatakan bahwa untuk menghadapi era globalisasi dan pelaksanaan otonomi daerah, pegawai negeri dituntut agar meningkatkan prestasi kerja/kinerjanya.

Disiplin kerja juga dapat dikatakan sebagai uapaya meningkatkan kinerja pegawai dalam suatu instansi/perusahaan. Hetami (2008) mengatakan bahwa sikap disiplin dapat meningkatkan kinerja pegawai, dengan mengeluarkan peraturan yang harus dilakukan oleh tiap pegawai dalam rangka menjaga agar pegawai tetap berada dalam koridor aturan yang telah ditetapkan oleh Dinas Terkait dalam mencapai tujua. Peraturan yang ditetapkan Instansi, diharapkan mampu memupuk kesadaran pegawai untuk lebih disiplin.

Amran (2009) mengatakan bahwa disiplin mengandung makna proses latihan yang memperkuat koreksi dan sanksi, kendali untuk menciptakan ketertiban dan keteraturan, dan sistem aturan tata laku. Disiplin dikaitkan dengan latihan yang memperkuat, terutama ditentukan pada pikiran dan watak untuk menghasilkan kendali diri, kebiasaan untuk patuh dan sebagainya.

Sedangkan menurut Rivai (2004), Disiplin adalah suatu alat yang digunakan para pimpinan untuk berkomunikasi dengan pegawai agar mereka bersedia untuk mengubah suatu perilaku serta sebagai upaya untuk meningkatkan kesadaran dan kesediaan seseorang mentaati semua peraturan Instansi dan norma-norma sosial yang berlaku.

Dari penelitian awal yang dilakukan pada pegawai Badan Keuangan Kabupaten Limapuluh Kota diketahui tingkat disiplin kehadiran pegawai kurang baik seperti yang terdapat pada tabel tingkat kehadiran pegawai dibawah ini :

Tabel 1. Tingkat Kehadiran Pegawai Badan Keuangan Tahun 2020

\begin{tabular}{|l|l|}
\hline Bulan & Persentase $(\%)$ \\
\hline Januari & 95,24 \\
\hline Februari & 86,43 \\
\hline Maret & 87,62 \\
\hline April & 65,24 \\
\hline Mei & 58,81 \\
\hline Juni & 77,62 \\
\hline Juli & 68,81 \\
\hline Agustus & 65,24 \\
\hline
\end{tabular}




\begin{tabular}{|l|l|}
\hline September & 58,81 \\
\hline Oktober & 57,62 \\
\hline November & 77,62 \\
\hline Desember & 78,81 \\
\hline
\end{tabular}

Sumber : Badan Keuangan Kabupaten Lima Puluh Kota, 2021

Tabel 1 diatas menunjukkan bahwa tingkat disiplin kehadiran Pegawai Negeri Sipil Badan Keuangan Kabupaten Lima Puluh Kota selama tahun 2020 yang dilihat dari 12 bulan mulai bulan Januari - Desmber 2020 tingkat kehadiran pegawai berdasarkan jam masuk kantor berfluktuasi kurang baik. Ini menjadi fenomena, masih ada pegawai yang tidak langsung melaksanakan aktifitas pekerjaan, yang mana hal ini dapat mempegaruhi kinerja pegawai dalam melaksanakan tugas dan fungsinya yang telah disusun secara terperinci oleh Instansi. Untuk menghindari hal diatas diperlukan adanya penilaian kinerja yang dapat mengarahkan dan memusatkan perhatian pegawai pada tugas, tujuan dan sasaran organisasi. Penilaian kinerja dapat juga memperlihatkan keadaan dan keterampilan dan mengidentifikasi kekurangan keterampilan.

Teori motivasi yang dikembangkan oleh Maslow pada intinya berkisar pada pendapat bahwa manusia mempunyai lima tingkat atau hierarki kebutuhan, yaitu : Fisiologis, keamanan keselamatan dan perlindungan, sosial, kasih sayang, rasa memiliki, penghormatan, rasa hormat internal seperti harga diri, prestasi, aktualisasi diri, dorongan untuk jadi apa yang mampu ia menjadi. Motivasi adalah dorongan, upaya dan keinginan yang ada dalam diri manusia yang mengaktifkan, memeberi daya serta mengarahkan perilaku untuk melaksanakan tugas-tugas dengan baik dilingkup pekerjaanya (Hakim, 2006). Menurur Maslow jika seorang pemimpin ingin memotivasi seseorang maka ia perlu memahami sedang berada pada anak tangga manakah posisi bawahan dan memfokuskan pemenuhan kebutuhan-kebutuhan itu atau kebutuhan ia atas tingkat itu, seorang pemimpin sangat perlu memperhatikan gaya kepemimpinan dalam proses memepengaruhi, mengarahkan serta mengkoordinasi tujuan anggota dan tujuan organisasi agar keduanya dapat tercapai

Menurut Simamora (2008) "Kinerja karyawan adalah tingkat dimana para karyawan mencapai persayaratan-persyaratan pekerjaan" sedangkan menurut Hasibuan (2006) menjelaskan bahwa : "Kinerja merupakan hasil kerja yang dicapai seseorang dalam melaksanakan tugas-tugas yang dibebankan kepadanya didasarkan atas kecakapan, pengalaman, kesungguhan serta waktu".

Fenomena yang ada pada Badan Keuangan Kabupaten Lima Puluh Kota pada saat ini masih rendahnya disiplin dan motivasi kerja pegawai. Kondisi ini terlihat dari masih belum adanya inisiatif dari pegawai untuk menyelesaikan pekerjaan-pekerjaan rutin dengan kesadaran sendiri, tapi masih menunggu perintah atasan, serta kurangnya kebersamaan, kekompakkan dan persamaan persepsi antara atasan dan bawahan yang berakibat pada tidak tercapainya capaian target kinerja.

Berdasarkan latar belakang masalah yang telah diuraikan di atas, maka rumusan masalah dalam penelitian ini adalah :

1. Bagaimana pengaruh disiplin kerja terhadap kinerja Pegawai Negeri Sipil pada Badan Keuangan Kabupaten Lima Puluh Kota. 
2. Bagaimana pengaruh motivasi kerja terhadap kinerja Pegawai Negeri Sipil pada Badan Keuangan Kabupaten Lima Puluh Kota.

3. Bagaimana pengaruh disiplin kerja dan motivasi kerja terhadap kinerja Pegawai Negeri Sipil pada Badan Keuangan Kabupaten Lima Puluh Kota.

\section{Tinjauan Literatur}

Disiplin Menurut Handoko (2017) mengemukakan disiplin adalah kegiatan manajemen untuk menjalankan standard organisasional, yang dilakukan dengan dua cara yaitu disiplin preventif dan disiplin korektif. Disiplin preventif adalah kegiatan yang dilaksanakan untuk mendorong para pegawai agar mengikuti standard dan aturan, sehingga penyelewengan-penyelewengan dapat dicegah. Sedangkan disiplin korektif adalah kegiatan yang diambil untuk menangani pelanggaran terhadap aturan aturan dan mencoba untuk menghindari pelanggaranpelanggaran lebih lanjut.

Hasibuan (2008) Istilah motivasi berasal dari bahasa latin yaitu moveree yang berarti bergerak atau menggerakkan. Motivasi diartikan juga sebagai suatu kekuatan sumber daya yang menggerakkan dan mengendalikan perilaku manusia. Motivasi sebagai upaya yang dapat memberikan dorongan kepada seseorang untuk mengambil suatu tindakan yang dikehendaki, sedangkan untuk mengambil suatu tindakan yang dikehendaki, sebagai motif dan daya gerak seseorang untuk berbuat. Karena perilaku seseorang cenderung berorientasi pada tujuan dan didorong oleh keinginan untuk mencapai tujuan tertentu.

Kinerja merupakan perilaku organisasi yang secara langsung berhubungan dengan produksi barang atau peyampaian jasa. Informasi tentang kinerja organisasi merupakan suatu hal yang sangat penting untuk mengevaluasi apakah proses kinerja yang dilakukan suatu organisasi selama ini sudah sejalan dengan tujuan yang diharapkan atau belum. Akan tetapi dalam kenyataannya banyak organisasi yang justru kurang atau bahkan tidak jarang ada yang mempunyai informasi tentang kinerja dalam organisasinya. Menurut (Mangkunegara, 2004) istilah kinerja berasal dari kata job performance atau actual performance (prestasi kerja atau prestasi yang sesungguhnya dicapai oleh seseorang). Sehingga dapat didefinisikan bahwa kinerja adalah hasil kerja secara kualitas dan kuantitas yang dicapai seorang pegawai dalam melaksanakan tugasnya sesuai dengan tanggung jawab yang diberikan padanya.

\section{Kerangka Pemikiran}

Melalui variabel pengaruh kepemimpinan dan motivasi terhadap kinerja pegawai secara skematis digambarkan seperti gambar dibawah ini : 


\section{Gambar 1. Kerangka Pemikiran}

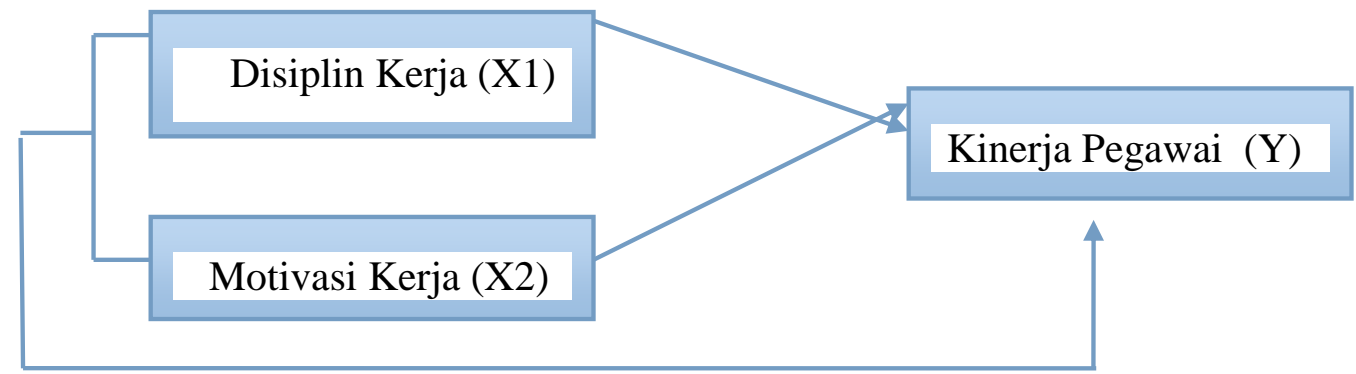

\section{Hipotesis}

Berdasarkan masalah yang dikemukakan di atas, maka penulis merumuskan hipotesa dalam penelitian ini adalah:

1. Diduga disiplin kerja berpengaruh positif dan signifikan terhadap kinerja Pegawai Negeri Sipil pada Badan Keuangan Kabupaten Lima Puluh Kota.

2. Diduga motivasi kerja berpengaruh positif dan signifikan terhadap kinerja Pegawai Negeri Sipil pada Badan Keuangan Kabupaten Lima Puluh Kota.

3. Diduga disiplin kerja dan motivasi kerja berpengaruh positif dan signifikan terhadap kinerja Pegawai Negeri Sipil pada Badan Keuangan Kabupaten Lima Puluh Kota.

\section{Metode Penelitian}

Penelitian ini dilakukan di Kantor Badan keuangan Kabupaten Limapuluh Kota Kota Payakumbuha, dan waktu penelitian dilakukan antara bulan Januari - Juli 2021.

\subsection{Jenis Penelitian}

Jenis penelitian yang digunakan adalah penelitian Desriftif yaitu Penelitian yang bertujuan untuk mengetahui Pengaruh antara variabel- variabel.Berdasarkan tujuan penelitian ini maka jenis penelitian ini termasuk survey analitik dengan menggunakan uji regresi barganda, dimana variabel indenpenden (mempengaruhi) dikategorikan menjadi tiga kategori dan denpenden (di pegaruhi) dikategorikaan menjadi satu kategori.

\subsection{Jenis Data}

Data adalah sekumpulan Fakta yang diperoleh meleluai pengamatan (observasi) langsung atau survey. Menurut Yakub (2012) sumber data dapat diperoleh dari berbagai sumber untuk memperolehnya. Dalam penelitian ini penulis akan menggunakan jenis dan sumber data yaitu:

Populasi merupakan sekelompok individu atau obyek yang memiliki karakteristik sama. Persamaan karakteristik dalam populasi misalnya sekelompok individu di masyarakat yang mempunyai umur, jenis kelamin, pekerjaan, status sosial yang sama Sugiyono (2014). Populasi dalam penelitian ini adalah seluruh Pegawai Negeri Sipil Badan Keuangan Kabupaten Lima Puluh Kota yang berjumlah 72 orang. Keseluruhan populasi tersebut dijadikan sampel dalam penelitian ini. 
Tabel 2. Data Populasi

\begin{tabular}{|l|l|l|}
\hline NO. & Jabatan Struktural & Jumlah \\
\hline 1. & Eselon II & 1 \\
\hline 2. & Esselon III & 7 \\
\hline 3. & Esselon IV & 21 \\
\hline 4. & Staf / Non Esselon & 43 \\
\hline & Jumlah & $\mathbf{7 2}$ \\
\hline
\end{tabular}

Sumber ; Badan Keuangan Kab. Lima Puluh Kota ( Tahun 2020)

\subsection{Sampel}

Menurut Fauzi, Dencik, Asiati (2019) sampel adalah bagian dari jumlah dan kaakteistik yang dimiliki oleh populasi tersebut. Sampel dalam penelitian ini adalah seluruh Pegawai Negeri Sipil di Badan Keuangan Kabupaten Lima Puluh Kota yang berjumlah sebanyak 72 orang dengan menggunakan metode sensus yaitu seluruh populasi jadi sampel. Hal ini sesuai dengan pendapat yang dikemukakan oleh Arikunto (2008) yang mengemukakan bahwa: "Apabila subjeknya kurang dari 100, lebih baik diambil semua sehingga penelitiannya merupakan penelitian Sensus dengan jumlah sampel 72 orang.

\subsection{Analisis Regrasi Linear Berganda}

Analisis ini digunakan untuk meneliti pengaruh dari beberapa variael independen (variabel X) terdapat variabel dpenden (variabel Y). (Gozali. 2016). Pada regresi berganda variabel independen yang diperhitungkan pengaruhnya terhadap variabel dependen, jumlahnya lbih dari satu, sehingga persamaan regresi berganda yang dipergunakan adalah :

$\mathrm{Y}=\mathrm{a}+b_{1} X_{1}+b_{2} X_{2}+\mathrm{c}$

Keterangan :

$\mathrm{a}=$ Konstanta

$\mathrm{Y}=$ Variabel Terikat (dependen), Kinerja Pegawai

$X_{1}=$ Variabel Bebas (independen), Disiplin Kerja.

$X_{2}=$ Variabel Bebas (independen). Motivasi kerja

b) =Nilai Konstanta

c) = Nilai Koefisien Regresi

$\mathrm{e}=$ Erorr (Faktor Pengganggu)

\subsubsection{Uji t ( Uji Parsial )}


Untuk mengetahui ada tiadaknya pengaruh variabel independen terhadapap variabel dependn, maka dilakukan pengujian terhadap pengujian terhadap hipotesis yang diajukan pada penelitian ini. Metode pengujian terhadap hipotensis yang diajukan dilakuan pengujian secara parsial menggunakan uji t. Uji t menunjukkan seberapa jauh pengaruh satu variabel independen scara individul dalam menerangkan variasi variabel dependen (Ghozali, 2016). Untuk menguji apakah masing-masing variabel independen berpengaruh secara signifikan terhadap variabel dependen secara parsial dengan menentukan derajat keprcayaan $95 \%(\mathrm{a}=$ $0,05)$ dan juga penerima atau pnolakan hipotesa, maka cara yang dilakukan adalah :

a. Apaila $\mathrm{t}$ hitung $>\mathrm{t}$ table, maka ada pengaruh signifikan antara variabel $\mathrm{X}$ masingmasing dengan variabel Y. (H0 ditolak dan Ho diterima).

b. Apabila $t$ hitung $<\mathrm{t}$ table, maka tidak ada pngaruh signifikan antara variabel $\mathrm{X}$ masing-masing dengan variabel Y. (Ho diterima dan $\mathrm{H} 0$ ditolak)

Atau biasa juga dengan menggunakan angka signifikan.

a. Apabila angka signifikan lebih kecil dari 0,05 maka Ho ditolak dan Ho diterima artinya ada pengaruh secara signifikan.

b. Apabila angka signifikan lebih besar dari 0,05 maka H0 diterima dan Ho ditolak artinya tidak berpengaruh secara signifikan.

Mencari t hitung dengan rumus

$\mathrm{b} 1=\frac{b_{1}}{s b_{1}}$

Keterangan :

$t_{o}=$ Nilai $t_{\text {hitung }}$

$\mathrm{b}_{1}=$ koefisien regresi

$s b_{1}=$ Standar deviasi atau konfisien regresi Xi. (Ghozali 2016).

\subsubsection{Uji Statistik F ( Uji Signifikansi Simultan )}

Digunakan untuk mengetahui pengaruh variabel independen terhadap variabel dependen, yaitu apakah variabel X1 dan X2 benar-benar berpengaruh secara bersama-sama terhadap variabel Y. Untuk menguji apakah masing-masing variabel bebas berpengaruh secara signifikan terhadap variabel terikat secara persial dengan menentukan derajat kepercayaan 95\% ( $\mathrm{a}=0.05$ ) dan juga penerimaan atau penolakan hipotesa, maka cara yang dilakukan adalah:

a. Apabila $\mathrm{F}$ hitung > $\mathrm{F}$ tabel, maka $\mathrm{H} 0$ ditolak dan Ho diterima, berarti masingmasing variabel independen secara bersama-sama mempunyai pengaruh yanga signifikan terhadap variabel dependen.

b. Mencari rumus F hitung ( Ghozali 2016)

$$
F_{\text {hitung }}=\frac{R^{2} /(k-1)}{\left(1-R^{2}\right) /(N-R)}
$$


Apabila F hitung < F tabel, maka HO diterima Ho ditolak, berarti masingmasing variabel independen secara bersama-sama didak mempunyai pengaruh yang signifikan terhadap variabel dependen.

Keterangan :

$$
\begin{aligned}
& R^{2}=\text { Koefisien Determinasi } \\
& k=\text { Banyaknya variabel bebas } \\
& \mathrm{n}=\text { Banyaknya sampel }
\end{aligned}
$$

\subsubsection{Uji Koefisien Determinasi $\left(\boldsymbol{R}^{2}\right)$}

Menurut Ghozali (2016), koefisien deteminasi $\left(R^{2}\right)$ pada intinya untuk mengukur persentase sumbangan variabel bebas yaitu variabel bebas yaitu variabel penilaian pengaruh disiplin kerja (X1) dan motivasi kerja (X2) terhadap kinerja pegawai Badan Keuangan Kabupaten Limapuluh Kota (Y) secara bersama-sama,diantara $0 \leq R^{2} \geq 1$. Menurut Ghozali (2016), model rumusnya sebagai berikut;

$$
R^{2}=\frac{n \sum x y-\sum x \sum y}{\sqrt{\left(n\left(\sum x^{2}\right)\left(\sum x\right)^{2}[-] n\left(\sum y^{2}\right)-\left(\left(\sum y\right)^{2}\right)\right.}}
$$

$$
\begin{aligned}
& \text { Keterangan : } \\
& R^{2}=\text { besar koefesien determinasi } \\
& \mathrm{X}=\text { nilai variabel } \mathrm{x} \\
& \mathrm{Y}=\text { nilai variabel } \mathrm{y}
\end{aligned}
$$

Besarnya $R^{2}$ dihitung memgagi jumlah yestimasi dikurangi rata-rata kuadrat (sum square) dengan jumlah Y terubsesi dikurangi Y rata-rata kuadrat.Nilai $R^{2}$ adalah 0 sampai dengan 1 , bila $R^{2}$ mendekati 1 maka modol yang dipilih mendekati kebenaran.

Koefisien dari b akan bernilai (+) jika menunjukkan huungan yang searah antara variabel prediktor dengan variel respon, artinya kenaikan pada variael prediktor akan mengakibatkan kenaikan pada variabel respon, begitu juga sebaliknya. Sedangkan nilai b akan (-) jika menunjukkan hubungan yang berlawanan, artinya apabila terjadi kenaikan pada variabel prediktor mengakibatkan penurunan pada variabel respon dan bila terjadi penurunan pada variabel prediktor maka variabel respon akan mengalami kenaikan (Ghozali,2016).

\section{Hasil dan Pembahasan}

\subsection{Uji Validitas}

Uji validitas menunjukan sejauh mana suatu alat pengukur berhubungan dengan suatu pengujian item-item dalam kuisioner yang akan digunakan. Dalam penelitian ini akan digunakan analisis korelasi yaitu dengan menghitung korelasi antara nilai keseluruhan yang diperoleh dari setiap butir pertanyaan dengan nilai keseluruhan atau skor totalnya. Skor total 
adalah skor yang diperoleh dari hasil penjumlahan semua skor item pernyataan. Apabila skor totalnya lebih besar dari 0,361 maka dapat dikatakan bahwa alat pengukur tersebut mempunyai validitas.

Tabel 3. Uji Validitas Variabel Disiplin Kerja (X1)

\begin{tabular}{|l|c|l|l|l|}
\hline No & Variabel / Indikator & r hitung & r tabel & Keterangan \\
\hline 1 & Disiplin kerja 1 & 0.575 & 0.361 & Valid \\
\hline 2 & Disiplin kerja 2 & 0.713 & 0.361 & Valid \\
\hline 3 & Disiplin kerja 3 & 0.367 & 0.361 & Valid \\
\hline 4 & Disiplin kerja 4 & 0.777 & 0.361 & Valid \\
\hline 5 & Disiplin kerja 5 & 0.607 & 0.361 & Valid \\
\hline 6 & Disiplin kerja 6 & 0.671 & 0.361 & Valid \\
\hline 7 & Disiplin kerja 7 & 0.595 & 0.361 & Valid \\
\hline 8 & Disiplin kerja 8 & 0.795 & 0.361 & Valid \\
\hline 9 & Disiplin kerja 9 & 0.473 & 0.361 & Valid \\
\hline 10 & Disiplin kerja 10 & 0.644 & 0.361 & Valid \\
\hline
\end{tabular}

Sumber : Hasil Pengolahan data Primer Tahun 2021

Berdasarkan Tabel 3 di atas, pengujian validitas dimulai dari uji validitas variabel disiplin kerja (X1) dari 10 butir pernyataan yang ada, ditemukan semua item Pernyataan valid untuk disiplin. Dari hasil uji validitas diperoleh semua nilai korelasi masing-masing lebih besar dari nilai korelasi kritis atau 0.361. Dengan demikian semua item Pernyataan variabel disiplin kerja (X1) dapat digunakan untuk pengujian lebih lanjut.

Selanjutnya berikut ini adalah hasil pengujian validitas untuk item Pernyataan pada variabel motivasi kerja (X2), akan disajikan pada Tabel 4 berikut ini:

Tabel 4. Uji Validitas Variabel Motivasi Kerja (X2)

\begin{tabular}{|l|c|l|l|l|}
\hline No & Variabel / Indikator & r hitung & r tabel & Keterangan \\
\hline 1 & Motivasi Kerja 1 & 0.691 & 0.361 & Valid \\
\hline 2 & Motivasi Kerja 2 & 0.640 & 0.361 & Valid \\
\hline 3 & Motivasi Kerja 3 & 0.534 & 0.361 & Valid \\
\hline 4 & Motivasi Kerja 4 & 0.740 & 0.361 & Valid \\
\hline 5 & Motivasi Kerja 5 & 0.384 & 0.361 & Valid \\
\hline 6 & Motivasi Kerja 6 & 0.519 & 0.361 & Valid \\
\hline 7 & Motivasi Kerja 7 & 0.461 & 0.361 & Valid \\
\hline 8 & Motivasi Kerja 8 & 0.370 & 0.361 & Valid \\
\hline 9 & Motivasi Kerja 9 & 0.472 & 0.361 & Valid \\
\hline 10 & Motivasi Kerja 10 & 0.621 & 0.361 & Valid \\
\hline
\end{tabular}

Sumber : Data Primer yang sudah diolah 2021

Berdasarkan Tabel 4 di atas, pengujian validitas dimulai dari uji validitas variabel motivasi kerja (X2) dari 10 butir pertanyaan yang ada dinyatakan semuanya valid, karena diperoleh semua nilai korelasi masing-masing lebih besar dari nilai korelasi kritis atau 0.361. Dengan demikian semua item Pernyataan variable motivasi kerja dapat digunakan untuk pengujian lebih lanjut. 
Selanjutnya berikut ini adalah hasil pengujian validitas untuk item Pernyataan pada variabel kinerja (Y), akan disajikan pada Tabel 5 berikut ini:

Tabel 5. Uji ValiditasVariabel Kinerja (Y)

\begin{tabular}{|l|l|l|l|l|}
\hline No & Variabel / Indikator & r hitung & r tabel & Keterangan \\
\hline 1 & Kinerja 1 & 0.655 & 0.361 & Valid \\
\hline 2 & Kinerja 2 & 0.470 & 0.361 & Valid \\
\hline 3 & Kinerja 3 & 0.474 & 0.361 & Valid \\
\hline 4 & Kinerja 4 & 0.577 & 0.361 & Valid \\
\hline 5 & Kinerja 5 & 0.769 & 0.361 & Valid \\
\hline 6 & Kinerja 6 & 0.519 & 0.361 & Valid \\
\hline 7 & Kinerja 7 & 0.578 & 0.361 & Valid \\
\hline 8 & Kinerja 8 & 0.366 & 0.361 & Valid \\
\hline 9 & Kinerja 9 & 0.745 & 0.361 & Valid \\
\hline 10 & Kinerja 10 & 0.379 & 0.361 & Valid \\
\hline
\end{tabular}

Sumber : Data Primer yang sudah diolah 2021

Berdasarkan Tabel 5 di atas, pengujian validitas dimulai dari uji validitas variabel kinerja (Y) dari 10 butir pertanyaan yang ada dinyatakan semuanya valid, karena diperoleh semua nilai korelasi masing-masing lebih besar dari nilai korelasi kritis atau 0.361. Dengan demikian semua item Pernyataan variable kinerja dapat digunakan untuk pengujian lebih lanjut.

\subsection{Uji Reliabilitas}

Analisis reliabilitas menunjukkan sejauh mana suatu instrument dapat memberikan hasil pengukuran yang konsisten apabila pengukuran diulang dua kali atau lebih. Metode yang digunakan dalam analisis reliabilitas ini adalah metode Cronbach Alpha. Nilai Cronbach Alpha (r alpha) dikatakan handal (reliabel) apabila memiliki Cronbach Alpha lebih dari 0,60 (Ghozali :2016).

Table 6. Hasil Pengujian Reliabilitas Variabel Penelitian

\begin{tabular}{|l|l|l|}
\hline Variabel & Cronbach Alpha & Keterangan \\
\hline Kinerja (Y) & 0.841 & Reliabel \\
\hline Disiplin kerja (X1) & 0.883 & Reliabel \\
\hline Motivasi kerja (X2) & 0.732 & Reliabel \\
\hline
\end{tabular}

Sumber : Data primer yang sudah diolah 2021

Dalam penelitian ini uji reabilitas dilakukan dengan melihat hasil perhitungan nilai cronbach alpha $(\alpha)$. Suatu variabel dikatakan reliabel jika memberikan nilai cronbach alpha $(\alpha)>60 \%$ yaitu bila dilakukan penelitian ulang dengan waktu dan dimensi yang berbeda akan menghasilkan kesimpulan yang sama. Tetapi sebaliknya bila alpha $(\alpha)<60$ maka dianggap kurang handal, artinya bila variabel-variabel tersebut dilakukan penelitian ulang dengan waktu yang berbeda akan menghasilkan kesimpulan yang berbeda (Ghozali, 2016).

Hasil pengujian reliabilitas dalam Tabel 6 menunjukkan bahwa semua variabel dalam penelitian mempunyai koefisien alpha $(\alpha)$ yang cukup besar yaitu $>0,60$ sehingga dapat dikatakan semua konsep pengukur masing-masing variabel dari kuesioner adalah reliabel yang berarti bahwa kuesioner yang digunakan dalam penelitian ini merupakan kuesioner yang 
handal.

\subsection{Analisis Regresi Linear Berganda}

Analisis regresi linear berganda digunakan untuk melihat pengaruh variable disiplin kerja dan motivasi kerja terhadap kinerja pegawai Pada Badan Keuangan Kabupaten Limapuluh Kota dan sekaligus dalam rangka membuktikan hipotesis yang diajukan dalam penelitian. Persamaan regresi linear berganda berguna untuk melihat pengaruh dari masing-masing variabel bebas terhadap variabel terikat dengan menggunakan pendekatan Ordinary Least Square (OLS). Hasil analisa regresi liner berganda dapat dijelaskan pada Tabel 7 berikut:

Tabel 7. Hasil Analisa Regresi Berganda

\begin{tabular}{|c|c|c|c|c|c|c|}
\hline \multirow{2}{*}{\multicolumn{2}{|c|}{ Model }} & \multicolumn{2}{|c|}{$\begin{array}{l}\text { Unstandardized } \\
\text { Coefficients }\end{array}$} & \multirow{2}{*}{ 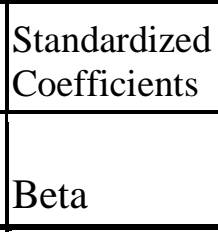 } & \multirow[b]{2}{*}{$\mathrm{t}$} & \multirow[b]{2}{*}{ Sig. } \\
\hline & & B & $\begin{array}{l}\text { Std. } \\
\text { Error }\end{array}$ & & & \\
\hline \multirow[t]{3}{*}{1} & (Constant) & 29.356 & 1.745 & & 16.824 & .000 \\
\hline & Disiplin kerja (X1) & .389 & .093 & .609 & 4.189 & .000 \\
\hline & Motivasi kerja (X2) & .372 & .014 & .383 & 3.570 & .008 \\
\hline
\end{tabular}

a. Dependent Variable: Kinerja (Y)

Sumber: Hasil Pengolahan Data Primer, 2021

Kemudian nilai koefisien regresi masing - masing variabel diatas dapat disubtitusikan ke dalam persamaan regresi linear berganda sebagai berikut :

$\mathrm{Y}=29,356+0,389 \mathrm{X} 1+0,372 \mathrm{X} 2$

Dari persamaan tersebut dapat dijelaskan bahwa nilai koefisien regresi untuk masing-masing variabel, nilai konstanta sebesar 29,356 satuan hasil ini menunjukkan bahwa apabila disiplin kerja dan motivasi kerja nilainya nol maka kinerja pegawai Pada Badan Keuangan Kabupaten Limapuluh Kota sudah ada sebesar 29,356 satuan dengan asusmsi variabel lain tetap.

Kemudian nilai koefisien regresi disiplin kerja (X1) adalah sebesar 0,389 satuan berpengaruh positif terhadap kinerja pegawai Pada Badan Keuangan Kabupaten Limapuluh Kota, artinya apabila disiplin kerja ditingkatkan sebesar satu satuan maka kinerja pegawai Pada Badan Keuangan Kabupaten Limapuluh Kota juga akan meningkat sebesar 0,389 satuan dengan asumsi variabel lain tetap.

Kemudian koefisien regresi motivasi kerja (X2) adalah sebesar 0,372 satuan artinya berpengaruh positif terhadap kinerja pegawai Pada Badan Keuangan Kabupaten Limapuluh Kota, apabila motivasi kerja ditingkatkan satu satuan maka kinerja pegawai Pada Badan Keuangan Kabupaten Limapuluh Kota juga akan meningkat sebeasar 0,372 satuan dengan asumsi variabel lain tetap. 


\subsection{Pengujian Hipotesis (Uji T)}

Berdasarkan perhitungan pada Tabel 7 diatas pengujian hipotesis secara parsial. Dari hasil uji $\mathrm{t}$ pada tabel 7 di atas dapat di jelaskan bahwa dari variabel independen yang di uji dengan uji $\mathrm{t}$ terlihat nilainya sebesar 4,189 $\mathrm{t}$ hitung sedangkan $\mathrm{t}$ tabel 1,986 artinya $\mathrm{t}$ hitung $>\mathrm{t}$ tabel sehingga dapat dikatakan disiplin kerja (X1) berpengaruh signifikan terhadap kinerja pegawai Pada Badan Keuangan Kabupaten Limapuluh Kota, begitu juga jika dilihat dari tingkat signifikan bahwa nilai signifikansi dari variabel disiplin kerja sebesar 0,000 artinya lebih kecil dari tingkat signifikansi yang di tetapkan yaitu 0,05 sehingga hipotesa yang di ajukan diduga disiplin kerja berpengaruh positif dan signifikan terhadap kinerja pegawai Pada Badan Keuangan Kabupaten Limapuluh Kota dalam penelitian ini dapat diterima dengan tingkat kepercayaan $95 \%$.

Kemudian variabel kedua dengan nilai $t$ hitung yaitu sebesar 3,570 sedangkan $t$ tabel 1,986 artinya thitung > t tabel sehingga dapat dikatakan bahwa motivasi kerja (X2) berpengaruh signifikan terhadap kinerja pegawai Pada Badan Keuangan Kabupaten Limapuluh Kota, jika dilihat dari tingkat signifikansi dari variabel motivasi kerja (X2) yaitu sebesar 0,008 artinya lebih kecil dari 0,05 sehingga hipotesa yang di ajukan diduga motivasi kerja berpengaruh positif signifikan terhadap kinerja pegawai Pada Badan Keuangan Kabupaten Limapuluh Kota dapat diterima dengan tingkat kepercayaan $95 \%$.

\subsection{Uji F ( Pengujian Hipotesis Secara Bersama-Sama)}

Untuk menguji pengaruh variabel bebas secara bersama - sama diuji dengan menggunakan uji F. Hasil perhitungan regresi secara bersama - sama diperlihatkan pada Tabel 8 dibawah ini :

Tabel 8. Hasil Uji F Simultan

ANOVA ${ }^{b}$

\begin{tabular}{|ll|l|l|l|l|l|}
\hline Model & & Sum of Squares & df & Mean Square & F & Sig. \\
\hline 1 & Regression & 308.602 & 2 & 154.301 & 26.589 & $.000^{\mathrm{a}}$ \\
& Residual & 220.520 & 38 & 5.803 & & \\
& Total & 529.122 & 40 & & & \\
\hline
\end{tabular}

a. Predictors: (Constant), Motivasi (X2), Disiplin (X1)

b. Dependent Variable: Kinerja (Y)

Sumber : Hasil Pengolahan data Primer Tahun 2021

Berdasarkan keterangan tabe 8 diatas dari hasil uji signifikan F didapat nilai signifikansi 0,000 dan F hitung 26,589 sedangkan F tabel sebesar 4,100 ini berarti bahwa model regresi dapat digunakan untuk memprediksi variabel terikat yaitu kinerja pegawai Pada Badan Keuangan Kabupaten Limapuluh Kota, karena nilai $\mathrm{f}$ hitung $>$ dari $\mathrm{f}$ tabel begitu juga dengan nilai signifikansinya $<0,05$. Dengan demikian, dapat diartikan bahwa variabel disiplin kerja dan motivasi kerja secara bersama - sama berpengaruh signifikan terhadap kinerja pegawai Pada Badan Keuangan Kabupaten Limapuluh Kota (Y). Oleh karena itu hipotesa yang 
diajukan dalam penelitian ini yang menyatakan bahwa diduga disiplin kerja dan motivasi kerja secara bersama - sama berpengaruh signifikan terhadap kinerja pegawai Pada Badan Keuangan Kabupaten Limapuluh Kota dapat diterima.

\subsection{Koefisien Determinan}

Koefisien determinan digunakan untuk melihat kontribusi dari variabel yang penulis teliti secara keseluruhan terhadap variabel terikat, dan dapat dilihat pada tabel 9 dibawah ini:

Tabel 9 Uji Koefisien Determinan

Model Summary ${ }^{\mathrm{b}}$

\begin{tabular}{|l|l|l|l|l|l|}
\hline Model & $\mathrm{R}$ & R Square & $\begin{array}{l}\text { Adjusted } \\
\text { Square }\end{array}$ & $\begin{array}{l}\text { Rtd. Error of } \\
\text { the Estimate }\end{array}$ & Durbin-Watson \\
\hline 1 & $.764^{\mathrm{a}}$ & .583 & .561 & 2.40898 & 1.256 \\
\hline
\end{tabular}

a. Predictors: (Constant), Motivasi (X2), Disiplin (X1)

b. Dependent Variable: Kinerja (Y)

\section{Sumber : Hasil Pengolahan data Primer Tahun 2021}

Dari hasil uji Koefisien Determinan diperoleh nilai $\mathrm{R}^{2}$ sebesar 0,583 artinya kontribusi dari variabel disiplin kerja dan motivasi kerja terhadap kinerja pegawai Pada Badan Keuangan Kabupaten Limapuluh Kota adalah sebesar 58,3 \% artinya disiplin kerja dan motivasi kerja dapat dijelaskan sebesar 58,3\% terhadap kinerja pegawai Pada Badan Keuangan Kabupaten Limapuluh Kota sedangkan sisanya 41,7 \% lagi dipengaruhi variabel lain yang tidak termasuk dalam penelitian yang penulis lakukan ini.

\section{Kesimpulan}

Berdasarkan Tabel 7 di atas, diketahui hasil pengujian data dengan analisis regresi linear berganda bahwa variabel disiplin kerja memiliki pengaruh yang positif terhadap kinerja pegawai Pada Badan Keuangan Kabupaten Limapuluh Kota, artinya apabila disiplin kerja ditingkat kan terus maka kinerja pegawai Pada Badan Keuangan Kabupaten Limapuluh Kota juga akan meningkat karena memiliki pengaruh yang positif semakin baik disiplin kerja pegawai Pada Badan Keuangan Kabupaten Limapuluh Kota maka akan semakin meningkat kinerja pegawai pada Badan Keuangan Kabupaten Limapuluh Kota.

Kemudian variabel kedua yang penulis teliti adalah motivasi kerja memiliki pengaruh yang positif terhadap kinerja pegawai Pada Badan Keuangan Kabupaten Limapuluh Kota artinya apabila motivasi kerja ini ditingkatkan terus maka kinerja pegawai Pada Badan Keuangan Kabupaten Limapuluh Kota juga akan meningkat karena memiliki pengaruh yang positif terhadap kinerja pegawai pada Badan Keuangan Kabupaten Limapuluh Kota.

Berdasarkan hasil pengujian hipotesis pertama di atas, ditemukan bahwa disiplin kerja memiliki pengaruh yang signifikan terhadap kinerja pegawai Pada Badan Keuangan Kabupaten Limapuluh Kota, ini terlihat dari uji hipotesis yang di lakukan bahwa nilai signifikansi dari uji t dibawah dari tingkat signifikan yang ditetapkan yaitu 0,05 sehingga hipotesa yang di ajukan dapat diterima. 
Kemudian hipotesi kedua motivasi kerja berpengaruh signifikan terhadap kinerja pegawai Pada Badan Keuangan Kabupaten Limapuluh Kota. Hal ini dapata dilihat dari hasil uji t dengan nilai signifikan dibawah dari tingkat signifikansi yang ditetapkan yaitu 0,05 sehingga hipotesis yang di ajukan dapat diterima dengan tingkat kebenaran 95\%.

Kemudian disiplin dan motivasi secara bersama - sama berpengaruh signifikan terhadap kinerja pegawai Pada Badan Keuangan Kabupaten Limapuluh Kota karena nilai signifikan yang lebih kecil dari tingkat alpha yang ditetapkan sehingga hipotesa yang di ajukan dalam penelitian ini secara bersama- sama dapat diterima dengan tingkat kebenaran $95 \%$.

Dari hasil koefisien determinan yang diperoleh dapat dilihat bahwa variabel disiplin kerja dan motivasi kerja memberikan kontribusi yang besar terhadap kinerja pegawai Pada Badan Keuangan Kabupaten Limapuluh Kota, sedangkan sisanya dipengaruhi variabel lain yang tidak termasuk dalam penelitian yang penulis lakukan ini. Keterbatasan penelitian ini adalah jumlah sampel yang sebaiknya mewakili seluruh populasi, saran untuk peneliti selanjutnya adalah agar menambahkan variabel lain diluar variabel yang diteliti oleh penulis dalam penelitian ini.Penelitian yang akan datang diharapkan, untuk memperluas model penelitian ini dan menambahkan beberapa faktor-faktor yang mempengaruhi Kinerja dari variabel yang peneliti gunakan ini, sehingga pada masa yang akan datang kita dapat menemukan bentuk model penelitian yang lebih baik untuk penelitian seperti ini. Pemimpin juga harus hadir di tempat saat memberikan instruksi kepada para bawahannya agar bawahan termotivasi untuk melakukan hak dan kewajibanya sesuai dengan pekerjaannya.

\section{Referensi}

Adietya Arie Hetami, 2008, Pengaruh Motivasi, Kemampuan dan Disiplin Terhadap Kinerja Karyawan pada Sebuah Persero Asuransi. Universitas Mulawarman Samarinda, Jurnal Ekonomi dan Bisnis Vol 6 No. 2 September-ISSN 1426435.

Arikunto, S. 2008. Prosedur Penelitian Suatu Pendekatan Praktik. Jakarta: Rineka Karya.

Amran. 2009. Pengaruh Disiplin Kerja Terhadap Kinerja Pegawai Kantor Departemen Sosial Kabupaten Gorontalo, Jurnal Ichsan Gorontalo, Vol 4, No 2 edisi Mei-Juli 2009.www.scribd.com/mobile/doc/290631854/Jurnal ichsan-Gorontalo-Vol-3-No2.

A.A Anwar Prabu Mangkunegara. 2004. Manajemen Sumber Daya Manusia. Bandung: Remaja Rosda Karya.

Aksara. Metodelogi Penelitian Untuk Skripsi dan Tesisi Bisnis. Jakarta : P Gramedia Pustaka.

Fauzi, F., Dencik, A. B., \& Asiati, D. I. (2019). Metodologi Penelitian untuk manajemen dan akuntansi. Jakarta: Salemba Empat.

Ghozali, Imam. 2016. Aplikasi Analisis Multivariete Dengan Program IBM SPSS 23 (Edisi 8). Cetakan ke VIII. Semarang : Badan Penerbit Universitas Diponegoro.

Hakim, Abdul. 2006. Analisis Pengaruh Motivasi, Komitmen Organisasi Dan Iklim Organisasi Terhadap Kinerja Pegawai Pada Dinas Perhubungan Dan Telekomunikasi Provinsi Jawa Tengah. JRBI. Vol 2. No 2. Hal: 165- 180.

Henry Simamora. 2008. Manajemen Sumber Daya Manusia. Edisi 2. Yogyakarta. STIE 
YKPN.

Hasibuan, Malayu S.P, 2006, Manajemen Dasar, Pengertian, dan Masalah, Edisi Revisi, Bumi Aksara : Jakarta.

Handoko 2017 Manajemen Sumber Daya Manusia. Edisi Revisi Jakarta Bumi Hasibuan, Malayu. 2008. Manajemen Dasar, Pengertian, Dan Masalah. Jakarta: PT Bumi Aksara.

Rivai,Veithzal. 2004. Manajemen Sumber Daya Manusia Untuk Perusahaan. Jakarta:Grafindo.

Sugiyono. (2014). Metode Penelitian Pendidikan Pendekatan Kuantitatif, Kualitatif, dan R\&D. Bandung: Alfabeta.

Yakub. 2012, Pengantar Sistem Informasi, Graha Ilmu, Yogyakarta.

\section{Copyrights}

Copyright for this article is retained by the author(s), with first publication rights granted to the journal.

This is an open-access article distributed under the terms and conditions of the Creative Commons Attribution license (http://creativecommons.org/licenses/by/4.0/) 